This item was submitted to Loughborough's Research Repository by the author.

Items in Figshare are protected by copyright, with all rights reserved, unless otherwise indicated.

\title{
The benefits of using reduced item variable scales in marketing
}

\section{segmentation}

PLEASE CITE THE PUBLISHED VERSION

http://dx.doi.org/10.1080/13527266.2012.723026

PUBLISHER

(C) Taylor \& Francis (Routledge)

VERSION

AM (Accepted Manuscript)

LICENCE

CC BY-NC-ND 4.0

\section{REPOSITORY RECORD}

Taylor-West, Paul, James M. Saker, and Donna Champion. 2019. "The Benefits of Using Reduced Item Variable Scales in Marketing Segmentation”. figshare. https://hdl.handle.net/2134/10546. 
This item was submitted to Loughborough's Institutional Repository (https://dspace.lboro.ac.uk/) by the author and is made available under the following Creative Commons Licence conditions.

\section{creative
commons}

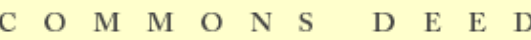

Attribution-NonCommercial-NoDerivs 2.5

You are free:

- to copy, distribute, display, and perform the work

Under the following conditions:

Attribution. You must attribute the work in the manner specified b the author or licensor.

Noncommercial. You may not use this work for commercial purposes.

No Derivative Works. You may not alter, transform, or build upon this work.

- For any reuse or distribution, you must make clear to others the license terms of this work.

- Any of these conditions can be waived if you get permission from the copyright holder.

Your fair use and other rights are in no way affected by the above.

This is a human-readable summary of the Leqal Code (the full license).

\section{Disclaimer 만}

For the full text of this licence, please go to: http://creativecommons.org/licenses/by-nc-nd/2.5/ 


\section{The benefits of using reduced item variable scales in marketing segmentation.}

\section{Introduction}

The automotive sector has made significant advances in providing alternative fuels to address green issues and has responded to consumer needs for interactivity and integration with new technology e.g. cell phones, portable music players and satellite navigation. A lot of these developments are complex and disruptive and there is evidence that these are not easily understood by consumers (Gibson 2010), for example electric powered, hybrid and fuel cell vehicles. And they are accompanied by new industry jargon such as 'range anxiety' (meaning the fear of the short distances that an electric powered vehicle can travel between charges before running out of power). Some changes are travelling at a pace that not all consumers may understand. Recently, it was announced that CD players will be missing from new cars in the near future as the connectivity between portable music players, such as the iPod, or music on USB sticks takes their place (McManus 2012). Some, but not all consumers will be comfortable with these innovative advances in technology and terminology.

It is suggested that consumer perceptions of new automotive products are moderated by how involved they are with cars (Taylor-West et al. 2008; Lennox and MacClarren 2003; Shimp and Sharma 1983; Bloch, 1981) and also their degree of expertise in understanding new innovations (Taylor-West et al. 2008; Kleiser and mantel 1999). This suggests that due to these differences marketing communications need to deliver differing messages to address these differences, for example novices will need greater detail to understand the benefit of 'torque vectoring control' (a system that improves handling stability when cornering), (Wood 2012), compared to an expert. It has been reported that there is insufficient information for consumers to make a 
judgement on the developments and changes that are taking place within the automotive industry (Gibson 2010).

If involvement and expertise can be measured, and the data is incorporated into consumer relationship management databases (CRM's), it will provide a useful tool to segment the consumer base to target these differing messages. However, adding more questions to the data collection process for CRM's as well as other forms of collection surveys, may make the burden of completion problematic, therefore there are clear benefits in using reduced item scales.

\section{Literature review}

Laurent and Kapferer (1985) suggest the purchase of an automobile is a highinvolvement purchase, a purchase that is based on personal needs, image and values that reflect individual differences. Bloch (1981) suggests this is the so-called 'love affair with the automobile' and that involvement with the product is a construct that varies across individuals, ranging from minimal levels to extremely high levels, that impacts their perception of new products.

To measure involvement an Automobile Involvement Scale (AIS) was developed by Bloch (1981). This started as a 66 item instrument, which was reduced to a 44 item and finally a 17 item instrument. Shimp and Sharma (1983) subsequently reduced this to 8 items through exploratory and confirmatory factor analysis. Results found the 8 -item scale accounted for $83.7 \%$ of the variance; they concluded that the 17 item scale (Bloch 1981) was excessive. Further research into the use of the 17-item and the 8-item scales was carried out by Lennox and McClaren (2003). Their findings supported the Shimp and Sharma (1983) reduced item scale and they also concluded that the 17-item scale was excessive and that a reduced item scale of 8 items could be used in the future. 
More recent research by Taylor-West et al. (2008) suggested that this could be reduced even further to two items - exploratory factor analysis indicating that a two item scale explained $77.89 \%$ of the variance. This may appear to be a quest for reduced item scales, but they do have significant benefits. Recent research revealed response rates to consumer questionnaires are declining (Anseel et al. 2010); it is suggested that shorter questionnaires are more likely to be completed, therefore if fewer item scales are developed that are reliable and valid as a longer scale, this would increase response rates. In addition, to carry out statistical analysis, it is suggested you need 10 (or more) times as many respondents as questions (Cohen et al. 2003; Hair et al. 1998; Pallant 2010). As many surveys have respondents in the 100's rather than 1000's, reduced item scales would be beneficial, particularly where variables are part of, rather than the main focus of the research, such as mediating variables (Pallant 2010).

Another major part of the evaluation of new automotive products is expertise. Alba and Hutchinson (1987), Gregan-Paxton and Roedder (1997) and Kleiser and Mantel (1999) found expertise to be an important moderator in the way consumers assess new products and more recent research suggests expertise increases pro-rata to the keen interest and involvement that one has with an automobile (Taylor-West et al. 2008), that is, the higher the interest and involvement, the higher the expertise.

Kleiser and Mantel (1999) developed a 55 item instrument to measure consumer expertise; which they was reduced to a 15-item scale using exploratory factor analysis. Subsequent research by Taylor-West et al. (2008) used 10 items from the Kleiser and Mantel (1999) study and suggested that this could be reduced further to 3 items; exploratory factor analysis showed a 3 item scale explained $87.4 \%$ of the variance. Again, the benefits of using a reduced item scale is clear when they are part of, rather than the main focus of, the research. 
In summary, this research questions if the reduced item Automobile Involvement Scale (AIS) and Expertise scale are reliable and valid when used in current automotive research.

\section{Method}

The objective of this study was to establish the current reliability and validity of using the reduced item scales of AIS and Expertise suggested by Taylor-West et al. (2008). Specifically, the objective was to test their 2 item instrument - Involvement, and 3 item instrument - Expertise.

The method selected to source primary data was a quantitative approach using self-administered questionnaires with visitors to the Geneva Motor Show in March, 2011. Data collection used a novel approach where respondents used the new Apple iPad to complete an online questionnaire - the collectors of the data were on hand to monitor and advise if necessary. The questionnaire was designed so that all questions had to be answered for completion. This method allowed for the controlled collection of specific information from the participants (Iacobucci and Churchill 2010).

\section{Short questionnaires rationale}

A previous study by Nakash et al. (2006) revealed that shorter questionnaires improved response rates by $9 \%$, but they warned of a trade-off between having enough items to answer the research question and making it so long that it had an adverse effect on response. Others have concluded that shorter questionnaires improve response rates (Baruch 1999; Baruch and Holtom 2008), but they suggested that there was insufficient evidence to suggest an optimal questionnaire length, in terms of number of questions or pages. However, Rolstad, Adler and Rydén (2011), suggest the amount of time taken to complete a questionnaire places a response burden on the respondent which is manifested in the response rate, if the burden is too high then the questionnaire may not 
be started at all or completion may be abandoned, resulting in a non-response. Therefore, shorter questionnaires in marketing communications are more likely to be completed, resulting in higher response rates. It appears that the benefits of using reduced item scales are clear, however, the purpose of this research was to test that the items used in the scale measured the same thing as the longer scale and added to the scientific based principles of reductionism and repeatability.

\section{Sample}

The survey was conducted over 2 public viewing days, Thursday $3^{\text {rd }}$ March and Friday $4^{\text {th }}$ March 2011. The venue was the Geneva Motor Show in Geneva, Switzerland. This was chosen because of its importance in the launch of new models in Europe for manufacturers and availability in terms of timings for the research schedule. Some 161 self-completion questionnaires were completed of which all were useable as they were completed online and they were designed to only be accepted if they were completed in full. This was in line with the study target of 150 . Only 2 people declined to fill in the questionnaire, resulting in a response rate of $98.77 \%$. It is believed that this high response rate was due to the high level of interest in the relatively new Apple iPad. As far as were aware we were the only researchers using this method of data collection at the motor show and we anticipated our novel method would attract people to participate in our questionnaire. It appears that the enthusiasm shown by the participants to use the iPad to complete the questionnaires showed our anticipation to be valid.

Eighty-nine percent of respondents were Male and $11 \%$ were Female. Fifty-one percent of respondents were in the sub-45 age group. 


\section{Methods and measures used}

Existing AIS and Expertise scales were used with two triangulation scales to test validity. Likert scales, on a range of 1 to $7(1=$ Strongly Disagree; $7=$ Strongly Agree $)$, were used throughout the survey.

\section{Existing scales}

The 2 item instrument - Involvement - proposed by Taylor-West et al. (2008) as a reduction of the Shimp and Sharma (1983) 8 item AIS scale, was used to measure Involvement. The two items used were as follows:

1) Cars offer me relaxation and fun when life's pressures build up.

2) Sometimes I get too wrapped up in my car.

The 3 item instrument - Expertise - proposed by Taylor-West et al. (2008) as a reduction of the Kleiser and Mantel (1999) 10 item Consumer Expertise scale, was used to measure Expertise. The three items used were as follows:

1) I enjoy learning about cars.

2) I can recall almost all existing brands of cars from memory.

3) I can recall almost all brand names of cars.

\section{Triangulation scales}

The purpose of the triangulation questions was to give content validity to the items used in the reduced scale and avoid pure reliance of the data reduction methods used by Taylor-West et.al (2008). Although Rossiter (2002) argues that content validity should not be established through correlation, his proposals are controversial and others argue that statements such as: " the validity of the instrument had been tested by comments of experts' or 'content validity was determined through a review of literature or panel experts' are unacceptable and invalid statements (Yaghmale 2009, p26). Pallant (2010) 
suggests that validity of a scale is that it measures what it is supposed to measure, but also points out that there is no universal agreement on what does indicate a scale's validity. The current paper sought to identify that there was a linear relationship between the scale items and the triangulation question and that the correlation establishes this relationship and validates the scale items.

The 8 item AIS scale developed by Shimp and Sharma (1983) was related to the enjoyment of driving, therefore, it is logical that a triangulation question directly related to the enjoyment of driving would be an appropriate question to ask. Similarly for the Expertise scale developed by Kleiser and Mantel (1999), in this case it is logical to ask a triangulation question that identifies if the respondent is an expert in automobiles. The questions used for the triangulation scales were reviewed by five expert judges in the automotive field, this panel agreed that they were appropriate and would be understood by respondents. Therefore, to test the validity of the Involvement and Expertise scales, the following triangulation questions (Likert Scales) were used:

1) I really enjoy driving (Involvement scale)

2) I would consider myself to be an expert on automobiles (Expertise scale)

\section{Scale properties, development and analysis parameters}

Pearson correlation was used to explore the strength of relationships between the interval (scales) variables. Confidence level used: $\mathrm{p}<.05$.

The triangulation question "I would consider myself to be an expert on automobiles “ was also tested for socially desirable responding bias using partial correlation; results show a positive correlation between Expertise and Involvement and the Marlowe-Crowne Social Desirability Scale showed little effect on the outcome:, there was only a small decrease in the strength of the correlation (from. - .398 to .371). 


\section{Results}

Results identified that Involvement had a large positive relationship with the triangulation scale (Pearson Correlation $r=.829, n=161, p<.05$ ). Note: $r=.50$ to 1.0 is considered to be a large relationship (Pallant 2010). According to Shimp and Sharma (1983), the AIS scale had good internal consistency with a Cronbach alpha coefficient reported of .84; the later study into AIS by Lennox and MaClaren (2003) reported 90. In the current study, the Cronbach alpha coefficient was .83 .

Results also identified that Expertise had a large positive relationship with the triangulation scale (Pearson Correlation $\mathrm{r}=.776, \mathrm{n}=161, \mathrm{p}<.05$ ). The Expertise scale by Kleiser and Mantel (1999) reported good internal consistency with a Cronbach alpha coefficient of .86; the later study by Taylor-West et al. (2008) reported .87 for the Expertise scale. In the current study the Cronbach alpha coefficient was .89 .

Findings also revealed a medium relationship between Involvement and Expertise (Pearson Correlation $\mathrm{r}=.398, \mathrm{n}=161, \mathrm{p}<.05$. - Note: $\mathrm{r}=.30$ to .49 is considered to be a medium relationship (Tables 1 and 2).

"Place table 1 about here"

"Place table 2 about here"

\section{Discussion and conclusion}

\section{Summary of findings}

The main aim of the research and the contribution to literature was to understand the engagement of the 'expert' mindset and that with the increase in the technological complexity of the car it is important for manufacturers to understand the different customer segments. In the luxury car market in particular, car's will soon be able to be improved with upgrades and 'apps' in a similar way to smart phones and understanding the 'market value' of such innovation will be of increasing importance to car manufacturers. Future research will also investigate the implications in a general 
sample so as to gain more insight into how perceptions of newness are impacted by engagement and involvement with a product. Cars are only one example of complex products where 'involvement' and perception of newness are becoming important; other examples include TV's; radio's; hifi systems etc. Therefore, our findings have possible application across other industries.

The findings show positive relationships exist between a consumer's expertise and their involvement with the product. This concurs with previous findings by TaylorWest et al. (2008) that expertise increases pro-rata to the involvement that one has with an automobile and adds to the literature relating to these areas of research. In addition, the indications are that reduced item scales will reduce any response burden felt by respondents when completing questionnaires and as a result will counteract declining response rates.

\section{Academic implications}

The findings provide a more holistic understanding of the contribution of 'involvement' and the expert mindset. Results suggest that the reduced 2 item scale for Involvement and the 3 item scale for Expertise are reliable; the high relationships to the triangulation scales give support to their validity - Involvement (Pearson Correlation $r=.829)-$ Expertise ((Pearson Correlation $r=.766)$, and they are particularly useful to researchers where they are used as part of, rather than the main focus of, the research, for example, as mediating variables.

This would facilitate the use of more mediating variables as the fewer items would be a lesser burden for completion on the respondents, it would also lessen the burden on achieving the response rate target for statistical analysis, for example, if the original 55 item scale for Expertise proposed by Kleiser and Mantel (1999) were used in a survey, then at least 550 responses (10 times as many respondents as questions) 
would be required for that construct alone (Cohen et al. 2003; Hair et al. 1998; Pallant 2010).

\section{Management implications}

There are also implications for automotive manufacturers as it would assist them in the targeting of new products by using the constructs as a segmentation tool in their marketing campaigns. Future consumer surveys and other data collection techniques should include questions to identify their consumer's Involvement and Expertise so they can tailor specific campaigns for these segments and communicate differing messages for those with high or low levels of Involvement and Expertise.

The real benefit of using the reduced item scales suggested in this research is that adding any questions to a survey increases the burden of completion on respondents and an increase in non-response rates. If the original 66 item scale for AIS proposed by Bloch (1981) and the 55 item scale for Expertise proposed by Kleiser and Mantel (1999) were added it would significantly increase the chances of a non-response rate, completion of surveys would become onerous and it is unlikely that practitioners could be persuaded to adopt the suggestions to measure these constructs.

\section{Conclusions}

It is suggested that reduced scales would be useful for any future automotive research projects where controlling variables are required to understand consumer perceptions, particularly where they are needed as part of, rather than the focus of, the research. For example, in the area of new product development, the perception of new products will differ considerably for novices compared to experts, particularly where complex and new disruptive technology is being introduced such as fuel cell vehicles. Also, the appeal of new products will vary considerably depending on consumer involvement 
with the product; an enthusiast is more likely to be interested in all the characteristics of a new product rather than those that just fit their own needs.

Whilst it is acknowledged that there have been numerous papers discussing the benefits of using reduced item scales most have been concerned with consumer behaviour and very few have been directly related to high value items or to products that are highly complex through their changing nature of rapid change and the use of new disruptive technologies, such as what is being witnessed currently in the automotive sector. It is also important to note that research methods and practices including established scales do not remain constant over time, by nature research is in a state of flux and scale items that may well have been reliable and valid in 1981, such as the AIS developed by Bloch, may not hold today. In addition, unless all mutli-item scales have been subjected to reduced item scale testing you cannot generalise that this area has largely been covered by previous research, clearly this cannot be the case. Therefore the testing of the AIS and Expertise scales suggested by Taylor-West et al. (2008), specifically in the automotive sector, as any other research that validates and updates previous research suggestions and proposals, adds to the body of knowledge. This means that there are now two new reduced item scales that will benefit future research.

\section{Limitations and future research}

Limitations - because this research was carried out in the context of a motor show, there may be some bias in the results and findings, mainly due to the respondents being typically highly involved in cars and are more expert in the area of cars. However the findings of this study compare well to the previous research by Kleiser and Mantel (1999); Lennox and MaClarrren (2003) and Shimp and Sharma (1983) who used a more general public sample of car owners. This research deliberately targeted people who are interested in cars to explore the 'expert' and 'involved' end of the spectrum in 
order to understand that end of the spectrum. If a more general sample had been used it may have been difficult to gain any insight into the 'expert' and 'involved' mindset. However, the two reduced scales will be used and tested again in a larger automotive research project planned for the future with a non-motor show sample. It is also suggested that the Marlowe-Crowne Social Desirability Scale should be used in repeated samples to ensure reliability over time, and to check for reporting bias.

Finally, Rossiter (2002) stresses that when establishing scale items, the procedure should be to validate then through the process of expert agreement after preinterviews with target raters (those who would respond to the scales). Because this research was concerned with the reduction of items used in established scales (AIS and Expertise), reliance has been placed on the pretesting methods of the items used in the scales by the original authors, and although extensive validation was carried out by them using reviews of literature, interviews and advertising and editorial content, it has already been pointed out at that what may have been valid some years ago may not hold today. However, our reliance on this research is mitigated in part by the use of the single item triangulation questions to test that the items used in the scales were measuring the same thing as the longer scales.

\section{References}

Alba, J.W. \& Hutchinson, J.W. 1987, "Dimensions of Consumer Expertise", Journal of Consumer Research (1986-1998), vol. 13, no. 4, pp. 411.

Anseel, F., Lievens, F., Schollaert, E. \& Choragwicka, B. 2010, "Response rates in organizational science, 1995-2008: A meta-analytic review and guidelines for survey researchers", Journal of Business and Psychology, vol. 25, no. 3, pp. 335349.

Baruch, Y. 1999, "Response rate in academic studies-A comparative analysis", Human relations, vol. 52, no. 4, pp. 421-438. 
Baruch, Y. \& Holtom, B.C. 2008, "Survey response rate levels and trends in organizational research", Human Relations, vol. 61, no. 8, pp. 1139-1160.

Bloch, P.H. 1981, "An exploration into the scaling of consumers' involvement with a product class", Advances in consumer research, vol. 8, pp. 61-65.

Cohen, J., Cohen, P., West, S.G. \& Aiken, L.S. 2003, Applied multiple regression/correlation analysis for the behavioral sciences, 3rd edn, Lawrence Erlbaum Associates, Mahwah, N.J.

Gibson, T. 2010, Fri, 29 Oct-last update, RAC Future Car Challenge - Electric cars: are they the answer to our environmental problems? [Homepage of Telegraph Media Group Limited], [Online]. Available:

http://www.telegraph.co.uk/sponsored/motoring/future-carchallenge/8093045/Electric-cars-are-they-the-answer-to-our-environmentalproblems.html [2010, 11/05].

Gregan-Paxton, J. \& John, D.R. 1997, "Consumer learning by analogy: A model of internal knowledge transfer", Journal of Consumer Research, vol. 24, no. 3, pp. 266-284.

Hair Jr., J.F., Anderson, R.E., Tatham, R.L. \& Black, W.C. 1998, Multivariate data analysis: Fifth Edition, 5th edn, Prentice Hall, New Jersey.

Iacobucci, D. \& Churchill, G.A. 2010, Marketing Research: Methodological Foundations, South-Western, Cengage learning, Florence, Kentucky, USA.

Kleiser, S.B. \& Mantel, S.P. 1999, "Expertise: Consumer Expertise" in Handbook of marketing scales : multi-item measures for marketing and consumer behavior research, 2nd edn, Sage Publications, Thousand Oaks, California, pp. 71-72.

Laurent, G. \& Kapferer, J.N. 1985, "Measuring consumer involvement profiles", Journal of Marketing Research, vol. 22, no. 1, pp. 41-53. 
Lennox, N. \& McClaren, N., 2003. "Measuring consumer involvement: a test of the automobile involvement scale", Australian and New Zealand Marketing Academy. Conference (1st - 3rd December 2003: Adelaide, South Australia), pp. 364.

McManus, W. 15/1/2012-last update, Ford ejects in-car CD players - will you miss them? |Which? Conversation [Homepage of Which? Conversation - Transport and Travel], [Online]. Available: http://conversation.which.co.uk/transport-travel/fordejects-in-car-cd-players-will-you-miss-them/ [2012, 15/1/2012].

Nakash, R., Hutton, J., Jørstad-Stein, E., Gates, S. \& Lamb, S. 2006, "Maximising response to postal questionnaires-a systematic review of randomised trials in health research", BMC medical research methodology, vol. 6, no. 1, pp. 5-14. Pallant, J. 2010, SPSS Survival Manual, 4th edn, Open University Press, Maidenhead. Rolstad, S., Adler, J. \& Rydén, A. 2011, "Response Burden and Questionnaire Length: Is Shorter Better? A Review and Meta-analysis", Value in Health, vol. 14, pp. $1101-1108$

Rossiter, J.R. 2002, "The C-OAR-SE procedure for scale development in marketing", International Journal of Research in Marketing, vol. 19, no. 4, pp. 305-335.

Shimp, T. \& Sharma, S. 1983, "The Dimensionality of Involvement: A Test of the Automotive Involvement Scale", Winter Conference in Causal ModelingAmerican Marketing Association, , pp. 58.

Taylor-West, P., Fulford, H., Reed, G., Story, V. \& Saker, J. 2008, "Familiarity, expertise and involvement: key consumer segmentation factors", Journal of Consumer Marketing, vol. 25, no. 6, pp. 361-368.

Wood, C. , 2012 Ford Focus Torque Vectoring Control Explained|AutoGuide.com News [Homepage of Autoguide.com News], [Online]. Available: http://www.autoguide.com/auto-news/2010/12/2012-ford-focus-torque-vectoringcontrol-explained.html [2012, 6/3/2012]. 
Yaghmale, F. 2009, "Content validity and its estimation", Journal of medical education, vol. 3, no. 1, pp. 25-27.

Table 1

Reliability statistics (Cronbach alpha)

\begin{tabular}{|l|l|l|l|l|l|}
\hline & $\begin{array}{l}\text { Current } \\
\text { Study }\end{array}$ & $\begin{array}{l}\text { 2008 Study } \\
\text { by Taylor- } \\
\text { West et al. }\end{array}$ & $\begin{array}{l}\text { 2003 Study by } \\
\text { Lennox \& } \\
\text { MaClarren }\end{array}$ & $\begin{array}{l}\text { 1983 Study by } \\
\text { Shimp \& } \\
\text { Sharma }\end{array}$ & $\begin{array}{l}\text { 1999 Study by } \\
\text { Kleiser and } \\
\text { Mantel }\end{array}$ \\
\hline Expertise & .89 & .87 & n/a & n/a & .86 \\
\hline AIS Scale & .83 & .86 & .90 & .84 & n/a \\
\hline
\end{tabular}

Table 2

Correlations

\begin{tabular}{|ll|l|l|}
\hline & & Triangulation Scales & Expertise \\
\hline Involvement & Pearson Correlation & .829 & .398 \\
& Sig. (2-tailed) & .000 & .000 \\
& $\mathrm{~N}$ & 161 & 161 \\
\hline Expertise & Pearson Correlation & .776 & $\mathrm{n} / \mathrm{a}$ \\
& Sig. (2-tailed) & .000 & \\
& $\mathrm{~N}$ & 161 & \\
\hline
\end{tabular}

